\title{
Effects of Brain-Based Learning Approach on Students' Motivation and Attitudes Levels in Science Class
}

\author{
Erkan AKYÜREK \\ Isahocall Secondary School, Kirsehir/TURKEY
}

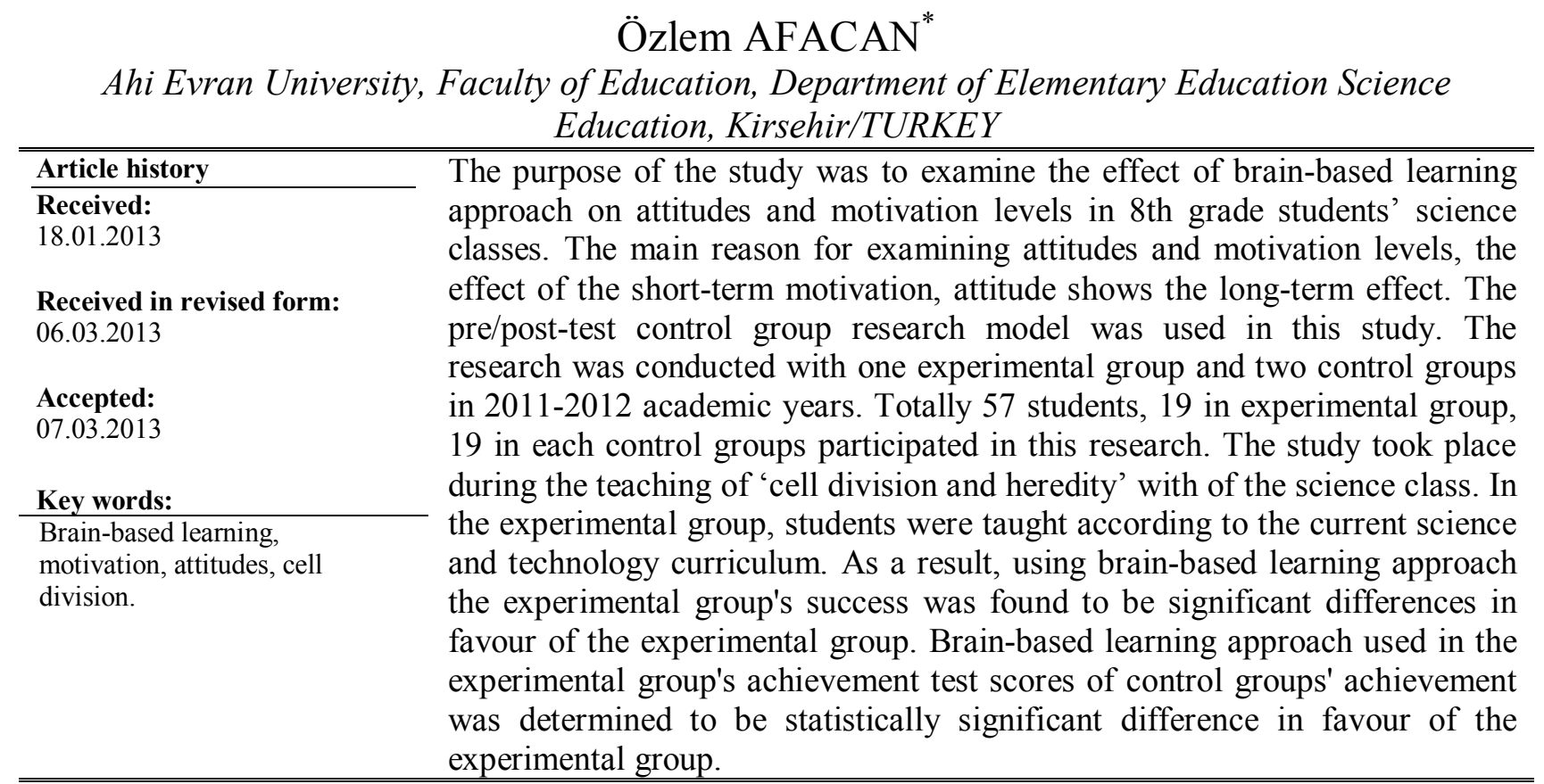

\section{Introduction}

\section{Background of the Study}

The adult human brain weighs about three pounds (1300-1400 grams) and is made up primarily of water ( 78 percent), fat (10 percent), and protein (8 percent) (Jensen, 1998). Although the brain is about 2 percent of an adult's weight, it consumes about 20 percent of the body's energy and its primary source of energy is blood which supplies nutrients like glucose, protein, trace elements, and oxygen to the brain (Sousa, 2001, p.15; Sprenger, 2002, p. 15). From the outside, the thick outer covering of the brain is called the cerebrum which consists of four paired lobes within two convoluted hemispheres. The cerebrum consists of two separate hemispheres (right and left) whose portions are connected internally by the corpus callosum, a bundle of nerve fibers that connect the left and right hemispheres. While the left hemisphere is responsible for analytical and verbal skills, such as reading, writing, and mathematics, the right hemisphere is the source of spatial and artistic kinds of intelligence. The outermost layer of each hemisphere is subdivided into four lobes, or sections, and each lobe carries out different functions. The frontal lobe (involving primary motor area, premotor area, frontal eye field area, and Broca's area) is the area around one's

\footnotetext{
* Ahi Evran University, Faculty of Education, Department of Elementary Education Science Education, Kirsehir/TURKEY, ozlemafacan2005@gmail.com
} 
forehead and primarily responsible for initiating voluntary motor control, providing responses relating to personality, mediating responses related to reasoning, judgment, planning, memory and emotions, and verbal communication The parietal lobe (involving general sensory area, somesthetic association area, and gustatory/taste area) is on the top back area. The temporal lobe (involving primary auditory area, auditory association area, vestibular area, and primary olfactory/smell area) is located below the parietal lobe and around the ear. The occipital lobe (involving primary visual area and visual association area) is in the middle back of the brain (Nunley, 2011). Gazzaniga, on the other hand, adds a new dimension to the discussion of the concept of consciousness by claiming that human beings have specialized systems that have evolved to enable human cognitive processes, and consciousness is the feelings humans have about their specialized capacities (Miller, 2003). According to the Brodnax (2004) the educational area of brain research began to gain more value after the 1980s. Leslie A. Hart, brain-based learning, or so-called brain-compatible teaching is known as the person who laid the foundations of the theory (Neve, Hart \& Thomas, 1986). Brain dominance' concept is used to express the dominance of one hemisphere of brain to the other in some specific function. Brain dominance tool was developed by Hermann (Özden, 2003, p. 77-80). The human brain is constantly evolving and adapting itself according to the new demands and challenges of the changing world. Moreover, real learning -being deeply personal- is almost always a deep struggle involving the adjustment of beliefs (Caine \& Caine, 2000). Brain Based Learning is a Learning approach that is based on the structure and function of the human brain. Distinct from current curriculum methods, brain based learning emphasizes meaningful learning instead of memorization.

The findings of neuroscience and psychology provide us with many opportunities of braincompatible implications for our classrooms. Key findings:

1. Mental Models - enhance teacher practice

2. Emotions - impact on student learning

3. Learning Environment - shaping student achievement

4. Memory - can't forget it!

5. Assessment - achievement and motivation

6. Biology of the Brain - pathway to understanding

7. The body, mind, and brain - all for one and one for all

8. Time - allotment and student achievement

9. Collaborative Learning - creating synergy

10. Thematic Instruction - enhances student learning

Brain-based teaching involves the implementation of carefully-designed principles with due consideration of their impact before, during, and after each lesson. The never-ending search for better teaching practices in this area has led educators to the work of key authors such as Caine, Caine, McClintic, and Klimek (2005), Erlauer (2003), Jensen (2005), Slavkin (2004), Wagmeister and Shifrin (2000), and Wolfe (2001). Most of these authors would agree with those teachers who contend they already incorporate some aspects of brain-based learning into their classrooms. However, they would also suggest that the pathway to more effective implementation follows a process of continual research, or sustained inquiry, which involves collaboration, planning, action, evidence-gathering, and reflection on practice.

In traditional educational settings in which the sole aim is the mere transmission of knowledge, teachers try to do the teaching without considering whether the learners are motivated, or whether attitudes towards lesson. However, today, through the findings of neuroscientists and psychologists, it is well documented that there is no separation of mind and emotions. Furthermore, emotions, thinking and learning are all linked (Bear, Connors \& Paradiso, 2001, p. 23). 


\section{Purpose of the Study}

The purpose of this study was to identify students' differences attitudes towards and motivation between brain based learning application in science class and current curriculum methods in science. To fulfil this aim, the following to questions were searched for answer:

Is there a statistically meaningful difference between the Science and Technology class of 8th grade students in primary school regarding "Cell Division and Heredity" unit who receive Brain Based Learning approached and current curriculum methods in Science and Technology class with regards to level of attitudes towards and motivation?

In addition to, sub problems are the following; according to gender is there a statistically meaningful difference between points of pre-test and final test of the students in experiment group?

Was there a change observed in the attitudes of students in experiment and control group towards science before and after the application of Brain Based Learning approach?

\section{Assumptions}

1. Uncontrollable variables, the experimental and control groups affected to the same extent.

2. The students reply to the tests sincerely without any influence, working done at the school.

\section{Method}

In this study was used pre/post-test control group research model from true experimental designs. The experimental pattern, motivations and attitudes of students is dependent variables. The independent variables on the dependent variables examined in this brain-based learning approach applied to students in force in the science and technology curriculum includes teaching methods.

Dependent and independent variables examined in the study, during research, analyzed the data obtained from the experimental and control groups. Gender of which independent variable, fall within the scope of classification scale.

\subsection{Universe-Sample}

This study was carried out in Kirsehir in the first half of 2011-2012 educational years. The study consists of 8th grade students of A Primary School. 57 equivalent students who were separated three groups by equalization participated in the study. 8/A control group-I, 8/B control group-II and 8/C experimental group were determined and each group made up from 19 students. The researcher was involved in experimental group and control group-I as the course designer and class instructor. The other science and technology lesson teacher was involved in control group-II as lesson instructor. To ensure the validity and objectivity of the researcher's (who was the class instructor at the same time) were chosen two control groups.

\subsection{Data Collection Instruments}

For the purpose of this study which aimed to investigate students' both motivation and attitudes towards science and technology lessons, quantitative data were collected. The quantitative data were collected through an attitude questionnaire and motivation questionnaire. Attitudes and motivation questionnaires were administered to the students to answer the research question on students' motivation and attitudes towards science and technology lessons. The most significant feature that separates from motivation to attitudes; motivation change short time the attitudes stems from the fact that change in the long time. Judgmental in the study, with the developed measuring 
instruments of applications converted into number and symbols, and with the appropriate statistical techniques were analyzed.

\section{Attitude Scale Toward Science and Technology Lesson}

In the research, a likert-type "Attitudes toward Science Learning" scale developed by Nuhoğlu (2008) was used to collect data. The scale is consists of three factors including 20 items (10 positive, 10 negative). Cronbach alpha reliability coefficient of SMTSL scale including 33 items was calculated 0.87 . In this study, Cronbach alpha reliability coefficient of Motivation toward Science Learning scale was calculated 0.78. This value is good for the scale to use. Data were analyzed by using a statistical package programme. Answer options of the scale items are; "agree, no opinion, disagree". In the analysis, 3-point was given for "agree" option while 1-point was given for "disagree" option for positive items. On the other hand, 1-point was given for "agree" option while 3-point was given for "disagree" option for negative items. Scores obtained from Attitude toward Science Learning scale changes between 20 and 60 points. Attitude items features, sub scales and item points were showed Table 1.

Table 1: Science and Technology Attitude Scale Scoring for Positive and Negative Items

\begin{tabular}{lcc}
\hline & $\begin{array}{c}\text { For Positive } \\
\text { Items }\end{array}$ & $\begin{array}{c}\text { For Negative } \\
\text { Items }\end{array}$ \\
\hline Agree & 3 & 1 \\
\hline No opinion & 2 & 2 \\
\hline Disagree & 1 & 3 \\
\hline
\end{tabular}

\section{Motivation Scale toward Science Learning}

In the research, a likert-type "Students' Motivation toward Science Learning" scale developed by Tuan, Chin and Shieh (2005) was used to collect data. The original language of the scale is English and consists of six factors including 33 items. This scale was translated into Turkish by Yılmaz and Çavaş (2007) and validity and reliability of it was calculated. Yılmaz and Çavaş (2007), Cronbach alpha reliability coefficient of Motivation toward Science Learning scale including 33 items was calculated 0.87 . In this study, Cronbach alpha reliability coefficient of Motivation toward Science Learning scale was calculated 0.73. The scale for experimental and control group students, before test procedure was applied and after the completion of the test procedure was applied too. In applications the researcher was present. The six factors used in the scale are; self-efficacy, active learning strategies, science learning value, performance goal, achievement goal and learning environment stimulation. "The Self-efficacy" factor comprises the beliefs that students hold about their individual competence in accomplishing tasks related to science. It is related to intrinsic motivation.

"The Active learning strategies" factor is related to feel intrinsic motivation when taking an active role in using a variety of strategies to construct students' new knowledge based on their previous understanding. "The Science learning value" factor is related to students' acquiring problemsolving competency, experience the inquiry activity, stimulate their own thinking, and find the relevance of science with daily life. It is related to intrinsic motivation. "The Performance goal" factor expresses that the student's goals in science learning are devoted to competing with the other students and attracting the attention of teacher. It is related to extrinsic motivation. "The Achievement goal" factor is related to students' specific goals which they should have for increasing their skills and success in science learning process. Also, it is related to extrinsic motivation. "The Learning environment stimulation" factor is related to the effect of learning environment components like curriculum, teachers' teaching methods and student's interaction on motivation. Also, it is related to extrinsic motivation. 
Data were analyzed by using a statistical package programme. Answer options of the scale items are; "strongly agree, agree, undecided, disagree, and strongly disagree". The subjects answered the items in the questionnaire on a Likert scale of 1 to 5, where 5 stood for "strongly agree", 4 stood for "agree", 3 stood for "undecided", 2 stood for "disagree", and 1 stood for "strongly disagree". In the analysis, 5-point was given for "strongly agree" option while 1-point was given for "strongly disagree" option for positive items. On the other hand, 1-point was given for "strongly agree" option while 5-point was given for "strongly disagree" option for negative items. Scores obtained from Motivation toward Science Learning scale changes between 33 and 165 points Motivation items features, sub scales and item points were showed Table 2.

Table 2: Motivation Scale Scoring for Positive and Negative Items

\begin{tabular}{lcc}
\hline & $\begin{array}{c}\text { For Positive } \\
\text { Items }\end{array}$ & For Negative Items \\
\hline Strongly agree & 5 & 1 \\
Agree & 4 & 2 \\
Undecided & 3 & 3 \\
Disagree & 2 & 4 \\
Strongly Disagree & 1 & 5 \\
\hline
\end{tabular}

\subsection{Data Analysis}

In this study, after "Attitude towards Science and Technology Questionnaire and Motivation Questionnaire" were used as pre-test/post-test, analysis of data was made by a packet program called SPSS for Windows.

\section{Findings}

In this chapter, collecting data of the study is given. Next findings data, the assessment of the study is presented as among groups within groups. Second, the results are reviewed. Finally, interpretations are given.

Table 3: Distribution of the Students According to Department Name and Gender

\begin{tabular}{llccccc}
\hline & \multirow{2}{*}{$\begin{array}{l}\text { Department } \\
\text { Name }\end{array}$} & Group & \multicolumn{3}{c}{ Female } & \multicolumn{2}{c}{ Male } & Sum \\
\cline { 2 - 6 } & & $\mathbf{N}$ & $\mathbf{\%}$ & $\mathbf{N}$ & $\mathbf{\%}$ & $\mathbf{N}$ \\
\hline 8/A & Control $^{1}$ Group I & 9 & 47.4 & 10 & 52.6 & 19 \\
8/B & Control $^{2}$ Group II & 11 & 57.9 & 8 & 42.1 & 19 \\
8/C & Experimental Group $^{3}$ & 10 & 52.6 & 9 & 47.4 & 19 \\
Sum & & 30 & 52.6 & 27 & 47.4 & 57 \\
\hline
\end{tabular}

${ }^{1}$ Control Group-I: Current curriculum methods in science were used (The researcher was involved in course instructor).

${ }^{2}$ Control Group-II: Current curriculum methods in science were used (The other Science and Technology teacher was involved in course instructor).

${ }^{3}$ Experimental Group: Brain based learning applications were used in science (The researcher was involved in course instructor).

Experimental Group and Control Groups Students Findings and Interpretations Association with Pre-Test Levels on Motivation 
Table 4: Experimental and control group 8 Grade Students, According to Pre-Test Scores on Attitude Measures of Central Tendency and Spread

\begin{tabular}{llll}
\hline Group & N & $\bar{x}$ & S \\
\hline Experimental Group & 19 & 48.21 & 5.52 \\
Control Group I & 19 & 50.05 & 4.62 \\
Control Group II & 19 & 46.79 & 8.36 \\
Total & 57 & 48.35 & 6.40 \\
\hline
\end{tabular}

When the results are analysed in Table 4, it is observed that all of the 57 students homogeneous in terms of attitudes towards science and technology is seen exhibited an average score of 48.35 are beginning to have an attitude.

Table 5: In the Experimental Group 8 Grade Students Relationship between Attitude Level toward Science Learning and Gender Pre-Test Results of Mann Whitney U-Test on Attitude Level by Gender

\begin{tabular}{lccccccc}
\hline Group & $\mathbf{N}$ & $\bar{x}$ & $\mathbf{S}$ & Mean Rank & $\begin{array}{c}\text { Sum of } \\
\text { Ranks }\end{array}$ & $\mathbf{U}$ & $\mathbf{p}$ \\
\hline Female & 10 & 49.70 & 5.10 & 11.65 & 116.50 & 28.50 & .176 \\
Male & 9 & 46.56 & 4.30 & 8.17 & 73.50 & & \\
\hline
\end{tabular}

As can be seen from the Table 5, gender has a significant effect on students' attitudes towards science learning. When " $\bar{x}$ " scores are examined, it is observed that female students' attitude level towards science learning $(\bar{x}=49.70)$ is higher than male students $(\bar{x}=46.56)$, one. But, there is not a significant difference between scores $(\mathrm{U}=28.5, \mathrm{p}=0.176)$. According to the results in the initial determined that experiment group students' attitude levels towards science learning does not change according to gender.

In the control group-I, 8 grade students' relationship between attitude level toward science learning and gender pre-test results were examined Table 6.

Table 6: In the Control Group-I 8 Grade Students Relationship Between Attitude Level Toward Science Learning and Gender Pre-Test Results of Mann Whitney U-Test on Attitude Level by Gender

\begin{tabular}{lccccccc}
\hline Group & $\mathbf{N}$ & $\bar{x}$ & $\mathbf{S}$ & Mean Rank & $\begin{array}{c}\text { Sum of } \\
\text { Ranks }\end{array}$ & $\mathbf{U}$ & $\mathbf{p}$ \\
\hline Female & 9 & 49.89 & 4.84 & 9.89 & 89.00 & 44.00 & .935 \\
Male & 10 & 50.20 & 4.64 & 10.10 & 101.00 & & \\
\hline
\end{tabular}

As can be seen from the Table 6, gender has a significant effect on students' attitudes towards science learning. When " $\bar{x}$ ” scores are examined, it is observed that male students' attitude level towards science learning $(\bar{x}=50.20)$ is higher than female students $(\bar{x}=49.89)$, one. But, there is not a significant difference between scores $(U=44, p=0.935)$. According to the results in the initial determined that control group-I students' attitude levels towards science learning does not change according to gender.

In the control group-II 8 grade students relationship between attitude level toward science learning and gender pre-test results were examined Table 7 . 
Table 7: In The Control Group-II 8 Grade Students Relationship Between Motivation Level

Toward Science Learning and Gender Pre-Test Results of Mann Whitney U-Test on Motivation Level by Gender

\begin{tabular}{lccccccc}
\hline Group & $\mathbf{N}$ & $\bar{x}$ & $\mathbf{S}$ & Mean Rank & $\begin{array}{c}\text { Sum of } \\
\text { Ranks }\end{array}$ & $\mathbf{U}$ & $\mathbf{p}$ \\
\hline Female & 9 & 48.82 & 6.70 & 11.14 & 122.50 & 31.50 & .301 \\
Male & 11 & 44.00 & 10.01 & 8.44 & 67.50 & & \\
\hline
\end{tabular}

As can be seen from the Table 5, gender has a significant effect on students' attitudes towards science learning. When " $\bar{x}$ " scores are examined, it is observed that female students' attitude level towards science learning $(\bar{x}=48.82)$ is higher than male students $(\bar{x}=44)$, one. But, there is not a significant difference between scores $(\mathrm{U}=31.5, \mathrm{p}=0.301)$. According to the results in the initial determined that experiment group students' attitude levels towards science learning does not change according to gender.

8th grade experimental and control group students in classes according to their gender, there was no difference 'attitudes towards science and technology, initially to be close to each other is important for all the features.

\section{Experimental Group and Control Groups Students Findings and Interpretations Association with Pre-Test Levels on Motivation and Gender}

Brain Based Learning Approach applications were used in experimental group and current curriculum methods were used control groups. As can be seen from Table 8, 8th grade students' motivation pre-test scores.

Table 8: Experimental and control group 8 Grade Students, According to Pre-Test Scores on

\begin{tabular}{lccc}
\multicolumn{4}{l}{ Motivation Measures of Central Tendency and Spread } \\
\hline Group & $\mathbf{N}$ & $\bar{x}$ & S \\
\hline Experimental Group & 19 & 125.89 & 9.14 \\
Control Group I & 19 & 122.89 & 9.49 \\
Control Group II & 19 & 125.74 & 11.47 \\
Sum & 57 & 124.84 & 10.00 \\
\hline
\end{tabular}

When the results are analysed in Table 8 , it is observed that all of the 57 students homogeneous in terms of motivation towards science and technology is seen exhibited an average score of 124.84 are beginning to have an attitude.

Table 9: In the Experimental Group 8 Grade Students Relationship between Motivation Level Toward Science Learning and Gender Pre-Test Results of Mann Whitney U-Test on Motivation Level by Gender

\begin{tabular}{lccccccc}
\hline Group & $\mathbf{N}$ & $\bar{x}$ & $\mathbf{S}$ & Mean Rank & $\begin{array}{c}\text { Sum of } \\
\text { Rank }\end{array}$ & $\mathbf{U}$ & $\mathbf{p}$ \\
\hline Female & 10 & 127.30 & 7.04 & 11.00 & 110.00 & 35.00 & .411 \\
Male & 9 & 124.33 & 11.26 & 8.89 & 80.00 & & \\
\hline
\end{tabular}

As can be seen from the Table 9, gender has a significant effect on students' motivation towards science learning. When " $\bar{x}$ " scores are examined, it is observed that female students' Motivation level towards science learning $(\bar{x}=127.30)$ is higher than male students $(\bar{x}=124.33)$, one. But, there is not a significant difference between scores $(\mathrm{U}=35, \mathrm{p}=0.411)$. According to the results in the initial determined that experiment group students' motivation levels towards science learning does not change according to gender. 
In the control group-I, 8 grade students' relationship between motivation level toward science learning and gender pre-test results were examined Table 10.

Table 10: In the Control Group-I 8 Grade Students Relationship Between Motivation Level Toward Science Learning and Gender Pre Test Results of Mann Whitney U-Test on Motivation Level by Gender

\begin{tabular}{lccccccc}
\hline Group & $\mathbf{N}$ & $\bar{x}$ & $\mathbf{S}$ & Mean Rank & $\begin{array}{c}\text { Sum of } \\
\text { Ranks }\end{array}$ & U & p \\
\hline Female & 9 & 120.44 & 7.90 & 8.94 & 80.50 & 35.50 & .437 \\
Male & 10 & 125.10 & 10.64 & 10.95 & 109.50 & & \\
\hline
\end{tabular}

As can be seen from the Table 10, gender has a significant effect on students' motivation towards science learning. When " $\bar{x}$ " scores are examined, it is observed that male students' motivation level towards science learning $(\bar{x}=125.10)$ is higher than female students $(\bar{x}=120.44)$, one. But, there is not a significant difference between scores $(U=35.5, p=0.437)$. According to the results in the initial determined that control group-I students' motivation levels towards science learning does not change according to gender.

In the control group-II, 8 grade students relationship between motivation level toward science learning and gender pre-test results were examined Table 11.

Table 11: In the Control Group-II 8 Grade Students Relationship Between Motivation Level Toward Science Learning and Gender Pre-Test Results of Mann Whitney U-Test on Motivation Level by Gender

\begin{tabular}{lccccccc}
\hline Group & $\mathbf{N}$ & $\bar{x}$ & $\mathbf{S}$ & Mean Rank & $\begin{array}{c}\text { Sum of } \\
\text { Rank }\end{array}$ & $\mathbf{U}$ & $\mathbf{p}$ \\
\hline Female & 11 & 124.00 & 13.20 & 11.19 & 100.50 & 34.50 & .433 \\
Male & 8 & 128.12 & 10.34 & 9.14 & 89.50 & & \\
\hline
\end{tabular}

As can be seen from the Table 9, gender has a significant effect on students' motivation towards science learning. When " $\bar{x}$ " scores are examined, it is observed that female students' Motivation level towards science learning $(\bar{x}=124.00)$ is smaller than male students $(\bar{x}=128.12)$, one. But, there is not a significant difference between scores $(U=34.5, p=0.43)$. According to the results in the initial determined that experiment group students' motivation levels towards science learning does not change according to gender.

8th grade experimental and control group students in classes according to their gender, there was no difference attitudes towards science and technology, initially to be close to each other is important for all the features.

As a result of the statistical 8 classes analysis conducted on the experimental and control groups, the dependent variable is that groups were similar in terms of the motivation score.

In addition, the motivation scores for groups of independent variables were examined with respect to gender, these variables were found to be equivalent in terms of groups.

According to the experimental and control groups of 8th grade science and technology courses attitudes toward arithmetical mean and standard deviation values for the post-test scores in Table 12 are also provided. 
Table 12: Experimental and control group 8 Grade Students, According to Post-Test Scores on Attitude Measures of Central Tendency and Spread

\begin{tabular}{llll}
\hline Group & N & $\bar{x}$ & S \\
\hline Experimental Group & 19 & 55.84 & 4.19 \\
Control Group I & 19 & 50.26 & 5.24 \\
Control Group II & 19 & 46.63 & 9.79 \\
Total & 57 & 50.91 & 7.74 \\
\hline
\end{tabular}

When Table 12 is examined, the results presented that Brain based learning applications were used students' (experimental group) attitude level towards science learning $(\bar{x}=55.84)$ is higher than Current curriculum methods were used students $(\bar{x}=50.26, \bar{x}=46.63)$. As control group-II was determined the lowest post-test level of attitudes towards science and technology lesson $(\bar{x}=$ 46.63).

Table 12.1: Post-Test Scoring of Attitude of Kolmogorov-Smirnov Test Among Groups

\begin{tabular}{cccc} 
Group & Kolmogorov-Smirnov(a) & & \\
\hline & Statistic & Sd & p \\
\hline 1 & .108 & 19 & .200 \\
2 & .134 & 19 & .200 \\
3 & .240 & 19 & .0051
\end{tabular}

As can be seen from the Table 12.1, since Kolmogorov-Smirnov p>.005 displayed data normally distributed. For this reason, parametric test, one-way analysis of variance (ANOVA) was performed. 8. grade students' attitudes towards science and technology for the post-test scores vary, for independent samples one-way analysis of variance (ANOVA) was performed, the results in Table 13 are given in. Attitudes towards science and technology, while the dependent variable, this variable is associated with a variable examined whether the experimental and control groups. Groups, experimental and control group-I and control group-II is divided into three levels. Therefore, as a result of the one-way analysis of variance, the difference between the two groups will be, in order to determine which of the two groups, Scheffe test was used for multiple comparisons. According to the Scheffe Test significant difference between the experimental group and control group-II, whereas there was no significant difference between the experimental group and the control-I.

Table 13: In the Experimental and Control Groups 8th Grade Students' Attitudes toward Science and Technology Course, Post-Test Scores Related to One-Way Analysis of Variance (ANOVA)

\begin{tabular}{lcccccc}
\hline $\begin{array}{l}\text { Source of } \\
\text { Variance }\end{array}$ & $\begin{array}{c}\text { Sum of } \\
\text { Squares }\end{array}$ & Sd & Mean Square & F & p & Sig \\
\hline Between Groups & 817.930 & 2 & 408.965 & 8.692 & .001 & $\mathbf{1 - 3}$ \\
Within Groups & 2540.632 & 54 & 47.049 & & & $\mathbf{2 - 3}$ \\
Total & 3358.561 & 56 & & & & \\
\hline *1: Control Group-I, 2: Control Group-II, 3: Experimental Group & & &
\end{tabular}

As seen from the Table 13, experimental group and control groups level have a significant differentiate on students' attitude toward science and technology course $\left(\mathrm{F}_{(2-54)}=8.692, \mathrm{p}<.05\right)$. In other words, between the attitude scores of experimental group and control groups varies according to experimental and control groups. Meaningful difference between the groups in which the Scheffe test to determine that the students of the experimental group $(\bar{x}=55.84)$ and the control group-I $(\bar{x}=50.26)$ of students in the experimental group are in favour of the students in the experimental group students $(\bar{x}=55.84)$ and the control group-II $\quad(\bar{x}=46.63)$, meaningful difference was found in favour of the experimental group students. 
Table 13.1: Attitude Post-Test Result between Groups According to Scheffe Test

\begin{tabular}{cccc}
\hline & $\mathbf{N}$ & \multicolumn{3}{c}{$\mathbf{p}=\mathbf{. 0 5}$} \\
\cline { 2 - 4 } Group* & \multicolumn{3}{c}{$\mathbf{2}$} \\
\cline { 2 - 4 } 2 & 19 & 46.63 & $\mathbf{1}$ \\
1 & 19 & 50.26 & 50.26 \\
3 & 19 & & 55.84 \\
P & & .273 & .051 \\
\hline *:1: Control group-I & 2: Control group-II & 3: Experimental group
\end{tabular}

According to 8th grade experimental and control groups associated with motivation post-test scoring arithmetic mean and standard deviation values are given in Table 14.

Table 14: Experimental and Control Group 8th Grade Students, According to Post-Test Scores on Motivation Measures of Central Tendency and Spread

\begin{tabular}{lccc}
\hline Group & N & $\bar{x}$ & S \\
\hline Experimental Group & 19 & 143.63 & 14.81 \\
Control Group I & 19 & 122.79 & 10.54 \\
Control Group II & 19 & 128.21 & 15.48 \\
Total & 57 & 131.74 & 16.10 \\
\hline
\end{tabular}

When Table 14 is examined, the results presented that Brain Based Learning applications were used students' (experimental group) motivation level towards science learning $(\bar{x}=143.63)$ is higher than Current Curriculum methods were used students $(\bar{x}=122.79$ and $\bar{x}=128.21)$. As control group-I was determined the lowest post-test level of motivation toward science and technology lesson $(\bar{x}=122.79)$.

8th grade students' motivation for post-test scores varies, for independent samples one-way analysis of variance (ANOVA) was performed, the results in Table 15 are given in. Motivation of the dependent variable, while the variable is examined whether it is associated with this variable, the experimental and control groups. Groups, experimental and control group-I and control group-II is divided into three levels. As a result of the one-way analysis of variance, the difference between the two groups will be, in order to determine which of the two groups; Scheffe test was used for multiple comparisons (Büyüköztürk, 2009).

Table 15: In the Experimental and Control Groups 8th Grade Students' Attitudes toward Science and Technology Course, Post-Test Scores Related to One-Way Analysis of Variance (ANOVA)

\begin{tabular}{lcccccc}
\hline Source of Variance & $\begin{array}{c}\text { Sum of } \\
\text { Squares }\end{array}$ & Sd & Mean Square & F & p & Sig. \\
\hline Between Groups & 4255.053 & 2 & 2127.526 & 11.189 & .000 & $\mathbf{1}-\mathbf{3}^{*}$ \\
Within Groups & 10268.000 & 54 & 190.148 & & & \\
Total & 14523.053 & 56 & & & & \\
\hline \multicolumn{2}{c}{ * Control Group-I, 2: Control Group-II, 3: Experimental Group } &
\end{tabular}

As seen from the Table 15, the results presented that Brain based learning applications were used students' (experimental group) motivation level towards science learning $(\bar{x}=143.63)$ is was found close to the value of the control group II students' ( $\bar{x}=128.21)$ motivation, higher than control group-I current curriculum methods were used students $(\bar{x}=123.37)$. As control group-II was determined the lowest post-test level of attitudes towards science and technology lesson $(\bar{x}=$ 46.63). 
Motivation post-test scores of the experimental group and control group-I in favour of the experimental group, between control group-I, control group-II and the experimental group and control group II, no significant difference is observed $\left(\mathrm{F}_{(2-54)}=11.189, \mathrm{p}<.05\right)$.

Table 15. 1: Motivation Post-Test Scheffe Test Results between Groups

\begin{tabular}{lccc}
\hline Group & $\mathbf{N}$ & \multicolumn{3}{c}{$\mathbf{p = . 0 5}$} \\
\hline & & 2 & 1 \\
\hline $\mathbf{1}$ & 19 & 123.37 & \\
$\mathbf{2}$ & 19 & 128.21 & 143.63 \\
$\mathbf{3}$ & 19 & & 1.000 \\
$\mathbf{p}$ & & .560 & \\
\hline
\end{tabular}

As seen from the Table 16 in the experimental group 8th grade students' relationship between motivation level toward science learning and gender were exhibited.

Table 16: Post-Test Results of Mann Whitney U-Test on Motivation Level by Gender

\begin{tabular}{lccccccc}
\hline Group & $\mathbf{N}$ & $\bar{x}$ & $\mathbf{S}$ & Mean Rank & Sum of Rank & $\mathbf{U}$ & $\mathbf{p}$ \\
\hline Female & 10 & 141.8 & 17.82 & 8.80 & 88.00 & 33.00 & .327 \\
\cline { 1 - 7 } Male & 9 & 145.67 & 11.29 & 11.33 & 102.00 & & \\
\hline
\end{tabular}

When Table 16 is examined, there is no difference between 8th grade experimental group student motivation post-test scores obtained from gender. $(U=33.00, p>.05)$.

As seen from the Table 17 in the control group-I 8th grade students' relationship between motivation level toward science learning and gender was exhibited.

Table 17: Post-Test Results of Mann Whitney U-Test on Motivation Level by Gender

\begin{tabular}{|c|c|c|c|c|c|c|c|}
\hline Group & $\mathbf{N}$ & $\bar{x}$ & $\mathbf{S}$ & Mean Rank & Sum of Rank & $\mathbf{U}$ & $\mathbf{p}$ \\
\hline Female & 9 & 123.00 & 11.69 & 10.17 & 91.50 & 43.50 & 902 \\
\hline Male & 10 & 123.70 & 10.03 & 9.85 & 98.50 & & \\
\hline
\end{tabular}

When Table 17 is examined, there is not difference between 8 th grade experimental group student motivation post-test scores obtained from gender $(U=43.50, p>.05)$

As seen from the Table 18 in the control group-II 8th grade students' relationship between motivation level toward science learning and gender were exhibited.

Table 18: Post-Test Results of Mann Whitney U-Test on Motivation Level by Gender

\begin{tabular}{|c|c|c|c|c|c|c|c|}
\hline Group & $\mathbf{N}$ & $x$ & $\mathbf{S}$ & Mean Rank & Sum of Rank & $\mathbf{U}$ & p \\
\hline Female & 11 & 32.44 & 4.44 & 9.77 & 107.50 & 41.50 & .836 \\
\hline Male & 8 & 28.63 & 4.75 & 10.31 & 82.50 & & \\
\hline
\end{tabular}

When Table 18 is examined, there is no difference between 8th grade experimental group student motivation post-test scores obtained from gender $(U=41.50, p>.05)$.

According to the results in the students' motivation towards science and technology courses taken post-tests scores can be said that does not change according to gender. 


\section{Result}

\section{The Findings Related to the Scores of the Students in the Experimental and Control Groups in the Pretest on their Attitudes towards Science and Technology}

The following section is a presentation of the findings related to the scores of the eight grade students, who were divided into three groups (experimental group, control group-I and control group-II), in the pre-test on their attitudes towards Science and Technology.

1. There were not any significant differences between the students in the experimental group and control groups in their scores in the pretest on their attitudes towards Science and Technology. In other words, the students in the experimental group and control groups had similar attitudes towards Science and Technology before the experiment.

2. The scores of the students in the experimental group, control group-I and control group-II in the pre-test on their attitudes towards Science and Technology did not differ significantly depending on gender. In other words, the variable "gender" did not have a significant influence on the attitudes of the students towards Science and Technology before the experiment.

\section{The Findings Related to the Scores of the Students in the Experimental and Control Groups in the Pre-Test on their Motivation towards Science and Technology}

The following section is a presentation of the findings related to the scores of the eight grade students, who were divided into three groups (experimental group, control group-I and control group-II), in the pretest on their motivation towards Science and Technology.

1. There were not any significant differences between the students in the experimental group and control groups in their scores in the pretest on their motivation towards Science and Technology. In other words, the students in the experimental group and control groups had similar levels of motivation towards Science and Technology before the experiment.

2. The scores of the students in the experimental group, who were taught via brain-based learning activities, and control group-I and control group-II, who were taught with the activities based on the current methods included in the curriculum, in the pre-test on their motivation towards Science and Technology did not differ significantly depending on gender. In other words, the students in all the three groups had similar characteristics before the experiment regardless of their gender.

\section{The Findings Related to the Scores of the Students in the Experimental and Control Groups in the Pre-Test and Post-Test on their Attitudes towards Science and Technology}

The following section is a presentation of the findings related to the scores of the eight grade students, who were divided into three groups (experimental group, control group-I and control group-II), in the pre-test and post-test on their attitudes towards Science and Technology.

1. The students in the experimental group, who were taught via brain-based learning activities, had higher scores in the posttest on their attitudes towards Science and Technology than control group-I and control group-II, who were taught with the activities based on the current methods included in the curriculum. It was observed that the brain-based learning activities had a statistically significant effect on improving the students' attitudes.

Tüfekçi (2005), Avcı (2007), Çelebi (2008), Bayındır (2003), Baş (2010), İnci (2010), Baştuğ and Korkmaz (2010) and Yücel (2011) maintain that brain-based learning has a significant influence on improving students' attitudes. On the other hand, Gets (2003), Aydin (2008), Samur (2009) and 
Yildirım (2010) hold that the approach neither has an influence on students' attitudes towards courses nor leads to changes in their attitudes.

2. An analysis was made of the correlation between the scores of the students in the experimental group in the pretest and posttest on their attitudes towards learning science. The analysis reported that their posttest scores were higher. As for the control groups, there was not a significant difference between the scores of the students in the pretest and posttest on their attitudes towards learning science. It was observed that the students' attitudes tended to get lowered in the course of time.

3. The scores of the students in the experimental group in the posttest on their attitudes towards learning science differed depending on gender. The female students had higher scores than the male students. However, the finding is contradicted by that of İnci (2010).

Studies on students' existing or potential attitudes in reference to gender have suggested different results. Therefore, it is essential that educational methods should be implemented regardless of gender.

\section{The Findings Related to the Scores of the Students in the Experimental and Control Groups in the Pre-Test and Post-Test on their Motivation towards Science and Technology}

The following section is a presentation of the findings related to the scores of the eight grade students, who were divided into three groups (experimental group, control group-I and control group-II), in the pre-test and post-test on their motivation towards Science and Technology.

1. The students in the experimental group, who were taught via brain-based learning activities, had significantly higher scores in the posttest on their motivation towards Science and Technology than control group-I and control group-II, who were taught with the activities based on the current methods included in the curriculum. It was observed that the brain-based learning activities were significantly effective in increasing the students' motivation. Similarly, Salmiza (2011) reported that brain-based learning approach is an effective instrument for increasing students' motivation.

2. An analysis was made of the correlation between the scores of the students in the experimental group in the pretest and posttest on their motivation. The analysis reported a significant difference. It was observed that the brain-based learning activities had a statistically significant influence on the students' motivation. Therefore, it can be concluded that brain-based learning activities improve students' motivation.

Similarly, Materna (2010) and Yildirım (2010) observed that the students in the experimental group, who were taught in accordance with brain-based teaching, were more motivated than the ones in the control group.

3. As for the control groups, there was not a significant difference between the scores of the students in the pre-test and post-test on their motivation. It was observed that the activities implemented were not effective in increasing the students' motivation. In addition, the scores of the students in the experimental group were not significantly influenced by gender.

\section{Discussion}

It is important to note consistency the between the Brain based learning approach for Science and effect of students attitude development. The measure of congruence on which this conclusion is based suggests that Brain Based Learning approach is both motivation and attitude. They were also found to be rigorous as indicated by the consistency between Brain Based Learning 
Approach and attitude, motivation scores from pre-test and post-test especially at eighth grade. Having substantiated their coherence, it is important to now move to the important task of implementing them. That task will be quite difficult, as the comparison of the attitude and motivation of the brain based learning approach to previous approaches shows-the range in consistency going from around $80 \%$ to $90 \%$. Tüfekci(2005), Avcı (2007), Çelebi (2008), Bayındır (2003), Baş (2010), İnci (2010), Baştuğ ve Korkmaz (2010), Yücel (2011) are good examples. For some states, between brain based learning and attitude of inconsistencies was more prevalent Gets (2003), Aydin (2008), Samur (2009) and Yildirım (2010). This exploratory analysis show that the Brain Based Learning Approach will actually improve the Science attitude and motivation of children once appropriately implemented is encouraging, if rather tentative. To interpret this as an indication of the likelihood that the Brain Based Learning Approach will be related to higher attitude and motivation requires adherence to a line of not unreasonable assumptions, but they are assumptions. The totality of the analyses we have done suggests a statistically significant positive relationship between attitude and the Brain Based Learning Approach, between motivation and Brain Based Learning Approach assessment, but is not only an indication of correlation but also of causality. On the other hand, combining these analyses with the strong of consistency that the Brain Based Learning Approach has with those of experimental group whose eighth-grade students attitude and motivation at the highest levels, makes the likelihood of such a relationship even greater. The relationship is even stronger when taking into account the prevalence of low-income students attending the state's public schools. Developed countries are now moving to implement Brain Based Learning Approach because of the closer relationship with attitude and motivation.

The other intriguing question that remains unanswered is, what is the relationship in terms of gender between attitude and brain based learning approach, motivation and brain based learning approach? Brain Based Learning Approach has essentially the same relationship of gender as defined by the Brain Based Learning Approach and student attitudes, Brain based Learning Approach and motivation. Our hypothesis, and somewhat supported by the data Materna (2000), Y1ldirim (2010), is that do irrespective of gender studies, it is important to practice teaching methods. It seems to us that it is time stop debating their quality and to move to assuring that they define current education methods at the classroom level-that is, what are actually being taught and all children. The evidence presented in this article seems, at least to the authors, to offer a vision of what can be. To not move in that direction and to continue to debate the issue is a mistake our children call ill afford.

\section{Implications for Further Research}

Further studies on the implementation of brain-based applications might look for the impact of such applications on student achievement. This is because although the current study did not have such an aim, during the process significant changes in student achievement and performance were observed; and thus, this aspect also needs to be investigated.

Further studies might implement this model for teaching other science skills, or other content courses after some modifications in its features about lesson.

Moreover, the number of studies conducted in the field of brain-based science learning is very limited in Turkey and in the world; therefore, there is a need for further research.

\section{Acknowledgement}

This study is a division of Erkan AKYÜREK's master thesis which is supervised by Asistant Professor Özlem AFACAN. 


\section{References}

Avc1, D. E. (2007). The effect of brain based learning approach to achievement, attitude and retention of knowledge in $7^{\text {th }}$ grade students' science classes of elementary school. (Unpublished Doctoral Dissertation). Gazi University, Ankara.

Aydın, S. (2008). Brain-Based learning theory-based impact on biology education academic achievement and attitude. (Unpublished master thesis). Gazi University, Ankara.

Baş, G. (2010). Effects of brain-based learning on students' achievement levels and attitudes towards English lesson. Elementary Education Online, 9(2), 488-507.

Baştuğ, M \& Korkmaz, İ. (2010). Applying strategies of brain based learning on the teaching social studies at the fifth grade. Journal of Selçuk University Ahmet Keleşoğlu Education Faculty, 29, 407-421.

Bayındır, H. (2003). An investigation of students' attitudes towards brain- based applications in English composition skills II course: A case study. (Unpublished master thesis). Middle East Technical University, Ankara.

Bear, M. F., Connor, B.W. \& Paradiso M.A. (2001). Neuroscience: Exploring the brain. Philadelphia, Lippincott Williams \& Wilkins.

Bransfod, J. D., Ann L. B., \& Rodney R. C. (1999). How people learn-brain, mind, experience and school, Washington, National Academy Press.

Brodnax, R. M. (2004). Brain compatible teaching for learning. (Unpublished PhD Thesis), Indiana University, Indiana.

Büyüköztürk, Ş. (2009). Sosyal bilimler için veri analizi el kitabı: İstatistik, araştırma deseni, SPSS uygulamalar1 ve yorum [Handbook data analysis for the social sciences: statistics, research pattern, SPSS applications and review]. Ankara: Pegem A Publication.

Caine, R. N. (2000). Building the bridge from research to classroom. Educational Leadership, 58 (3), 59-61.

Caine, G., Caine, R.N., McClintic, C. \& Klimek, K. (2005). 12 Brain/Mind learning principles in action. Thousand Oaks, CA: Corwin Press.

Çelebi, K. (2008). The effect of brain based learning on students achievement and attitude. (Unpublished master thesis). Selçuk University, Konya.

Erlauer, L. (2003). The brain-compatible classroom: Using what we know about learning to improve teaching. VA: ASCD, Alexandria.

Getz, C. M. (2003). Application of brain-based learning theory for community college developmental English students: A case study. (Unpublished PhD Thesis), Colorado State University, Colarado.

İnci, N. (2010). Brain-Based learning of science and technology achievement, attitude, and the effect of remembrance. (Unpublished master thesis). Firat University, Elazığ.

Jensen, E. (1998). Teaching with the brain in mind. Virginia, ASCD Publication.

Jensen, E. (2005). Teaching with the brain in mind. Alexandria, VA: ASCD.

Materna, L. (2010). Impact of concept-mapping upon meaningful learn and metacognition among foundation level associate degree nursing students. (Unpublished Doctoral Dissertation), Capella University, Chicago.

Miller, A.L. (2003). A descriptive case study of the implementation of brain- based learning with technological support in a rural high school. (Unpublished PhD Thesis). Northern Illinois University.

Neve, C.D., Hart, L.A. \& Thomas, E.C. (1986). Huge learning jumps show potency of brain-based instruction. Phi Delta Kappan, October, 143-148.

Nuhoğlu, H. (2008) Primary science and technology course system dynamics approach attitude, success and investigation of the effect of different skills. (Unpublished PhD Thesis), Gazi University, Ankara.

Nunley, F. (Jully 14, 1998). Brain biology: It's basic gardening. Retrieved February 3, 8 (2011), from http://help4teachers.com/gardening.htm. 
Nydia, M. C., Raquel A. \& Davidson A.L. (2005). What psychotherapists can begin to learn from neuroscience: Seven principles of a brain-based psychotherapy? Psychotherapy: Theory, Research, Practice, Training, 142 (3), 374-383.

Özden, Y. (2003). Öğrenme ve öğretme. [Teaching and learning].Ankara, Pegem A Publication.

Salmiza, S. (2011). The Effectiveness of the brain-based teaching approach in generating students' learning motivation towards the subject of physics: A qualitative approach. US-China Education Review A, 1, 63-72.

Samur, Y. (2009). Brain-based learning (e-learning) 7th grade students of elementary school English courses effect on academic achievement and attitudes towards the course. (Unpublished master thesis), Muğla University, Muğla.

Slavkin, M. (2004). Authentic learning: How learning about the brain can shape the development of students. Lanham, MD: Scarecrow Education.

Sousa, D. A. (2001). How the brain learns: A classroom teacher's guide. California, Corwin Press, Inc.

Sprenger, M. (2002). Learning \& memory: Brain in action. ASCD, Alexandra.

Tüfekçi, S. (2005) Brain-Based learning access, retention, attitude and learning process effect. (Unpublished Doctoral Dissertation). Hacettepe University, Ankara.

Tuan, H.L., Chin, C.C. \& Shieh, S.H. (2005). The development of a questionnaire for assessing students' motivation toward science learning. International Journal of Science Education, 27 (6), 639-654.

Wagmeister, J. \& Shirin, B. (2000). Thinking differently, learning differently. Educational Leadership, 58(3), 45-48.

Wolfe, P. (2001). Brain matters: Translating research into classroom practice. VA: ASCD, Alexandria.

Y1ldırım, Ö. (2010) The effect of brain based learning achievement, attitude and motivation. (Unpublished master thesis). Zonguldak Karaelmas University, Zonguldak.

Yılmaz, H. \& Çavaş, P. H. (2007). Reliability and validity study of the students' motivation toward science learning questionnaire. Elementary Education Online, 6(3), 430-440.

Yücel, C. (2011). According to brain-based learning approach to teaching science and technology impact on academic achievement and attitude. (Unpublished master thesis). Osmangazi University, Eskişehir. 